\title{
Great expectations: two tales of a city
}

\author{
I. Vojnovic ${ }^{1}$, L. A. Reese ${ }^{2}$, J. Eckert ${ }^{1} \&$ G. Sands ${ }^{3}$ \\ ${ }^{1}$ Geography, Michigan State University, USA \\ ${ }^{2}$ Global Urban Studies, Michigan State University, USA \\ ${ }^{3}$ Urban Planning, Wayne State University, USA
}

\begin{abstract}
After a decade long demographic and economic decline, culminating in America's largest municipal bankruptcy, many observers were ready to proclaim that Detroit was dead. Nevertheless, following the resolution of the bankruptcy and new municipal leadership, there has been a dramatic shift among academics and the popular press to documenting Detroit's recovery and resilience. Indeed, the rapid and dramatic turnaround in the city's fortunes appears to tell the stories of two different cities.

People and jobs are again returning to Detroit, along with levels of investment not seen for decades. These developments are, however, highly concentrated in Downtown and Midtown. The reality is that a strengthening core area is enjoying some measure of prosperity while the balance of the city continues to bleed population, jobs, and economic activity. The positive changes have done little to address the problems of a population that is poorly educated, lacks job skills and work experience, not to mention the problems of a deteriorating built environment and aged infrastructure.
\end{abstract}

Keywords: urban regeneration, Detroit, shrinking cities.

\section{Introduction}

"Everyone in Berlin wants to visit Detroit" [1];

"...the momentum that is building is exponential" [2];

"Detroit is revving up for the future...people are moving back into Downtown" [3];

"700,000 people, quiet, clean air, no pollution, democracy - what are you waiting for?" (Twitter feed in China) [4]; 
"An influx of young creative types is turning Detroit into a Midwestern TriBeCa" [5].

The concept of Shrinking Cities has emerged as a focus of academic research and policy debates in both Europe and the United States [6, 7]. Shrinking Cities suffer from extensive population decline along with economic decline, losses of income, employment and investment. Moreover, since the geographic boundaries of these cities generally do not shrink, a key issue for decision makers is how to continue to provide adequate levels of services despite declining resource availability [8, 9]. Research on this topic has focused on the development of useful taxonomies, identifying physical and fiscal consequences, charting the trajectories of decline and evaluating recovery strategies. While small to mid-size urban areas constitute most of the Shrinking Cities, some larger cities and urban areas also fall in this category.

Detroit can be distinguished from other Shrinking Cities in a number of ways, particularly in the magnitude of its shrinkage. Detroit's economic contraction parallels its demographic decline and the demographic and economic shrinkage of Detroit is greater than that of any other US city.

The loss of employment opportunities and businesses of all sorts has been just as extensive as the population decrease. The lack of jobs in the city, as well as the difficulty in reaching suburban jobs, contributes to high levels of unemployment, under employment and poverty. Although the decline in housing prices has kept the costs of homeownership affordable $(64.6 \%$ of the homes listed for sale in Detroit have an asking price less than the average price of a new car), low incomes and bad credit still put homeownership out of reach for many.

After decades of demographic and economic decline, culminating in America's largest municipal bankruptcy, many observers were ready to proclaim that Detroit was dead [10]. Nevertheless, following the resolution of the bankruptcy and new municipal leadership, there has been a dramatic shift among academics and the popular press to documenting Detroit's recovery and resilience. Detroit is a comeback kid, a cool place for young hipsters (and Chinese investors) to start businesses and buy homes, a hotspot for tourism with a vibrant art and restaurant scene, a gritty survivor that is well on its way to a full recovery. There are clearly pockets of prosperity evident in the City of Detroit (e.g. Midtown), but their geographic extent is limited. Thus, the turnaround in the city's fortunes appears to be the stories of two different cities.

Two primary research questions drive this analysis: Does the current positive image of Detroit reflect reality?; and, will any recovery culminate in a new Detroit that will provide residents with a quality of life that is sustainable in the decades to come? To answer these questions a longitudinal examination of trends on critical economic health and recovery variables are examined for the Midtown/Downtown area and the City of Detroit as a whole: population change; poverty; employment and business indicators; and property sales prices. This admittedly descriptive analysis serves as an important reality check on the widely touted "recovery" stories about Detroit, a check necessary so that the very significant problems remaining (and indeed, worsening) in the city at large do not become overlooked. The analysis is also important because it points to policy 
actions that have appeared to have strengthened the Midtown area leading to an assessment of whether such actions would promote sustainable recovery in the rest of the city, particularly for its residents.

The Midtown area of the city includes the cultural district composed of the Detroit Institute of Arts, the Detroit Central Library, the Detroit Science Center and Historical Museum, Wayne State University, and the Detroit Medical Center Complex. Formerly known as the Cass Corridor, the "Midtown" rebranding is the end of a long road from a strip known for prostitution, crime, and flop houses, to the cultural and entertaining hub it has become.

The discussion will proceed with a description of the extent of decline in the city in terms of population, racial change and segregation, employment, and poverty. This will be followed by presentation of data comparing Midtown and the rest of the city on key indicators: business starts and payroll, vacancy rates, employment, and housing prices. Lessons from the "recovery" of Midtown will conclude the paper.

\section{Growth, decline and "rebirth"}

\subsection{Boom Town Detroit: 1900-1950}

During the first three decades of the twentieth century, Detroit was the fastest growing major city in the U.S., increasing its population by almost 1.3 million (Figure 1). Much of this growth is attributable to the consolidation of the emerging auto industry. A second surge of population growth in the 1940s reflected Detroit's role as the 'Arsenal of Democracy' during WWII.

Detroit's boom years in the first half of the twentieth century planted the seeds of the city's decline in the latter half. Well-paying jobs in the auto plants were available even for those with minimal educational attainment levels; as a result, public education in the Motor City came to be undervalued. Detroit's era of rapid population increase was matched by construction that vastly expanded the physical city: housing, industrial and commercial buildings, as well as streets, water and sewer lines and government buildings [11]. This rapid growth a century ago has left Detroit with a public infrastructure that is now 80 to 110 years old, and nearing or at the end of its useful life.

\subsection{The reality of decline: $1950-2010$}

After 1950, Detroit's white population began to shrink, declining by more than 1.1 million by 2010 . This loss was only partially offset by an increase of 458,000 in Detroit's black population. The black population continued to grow until 1990; since then it has fallen by more than $215,000(27.6 \%)$.

A host of factors, both internal and external, have been blamed for Detroit's decline $[12,13]$. Internal forces (potentially under local control) include: governmental corruption, lack of action to effectively address declining resources; inability to collect taxes; and racial strife [14]. External drivers of decay (those not under local control) include: overreliance on an industry experiencing long term structural decline; poorly skilled labor pool; movement of jobs to the suburbs; 


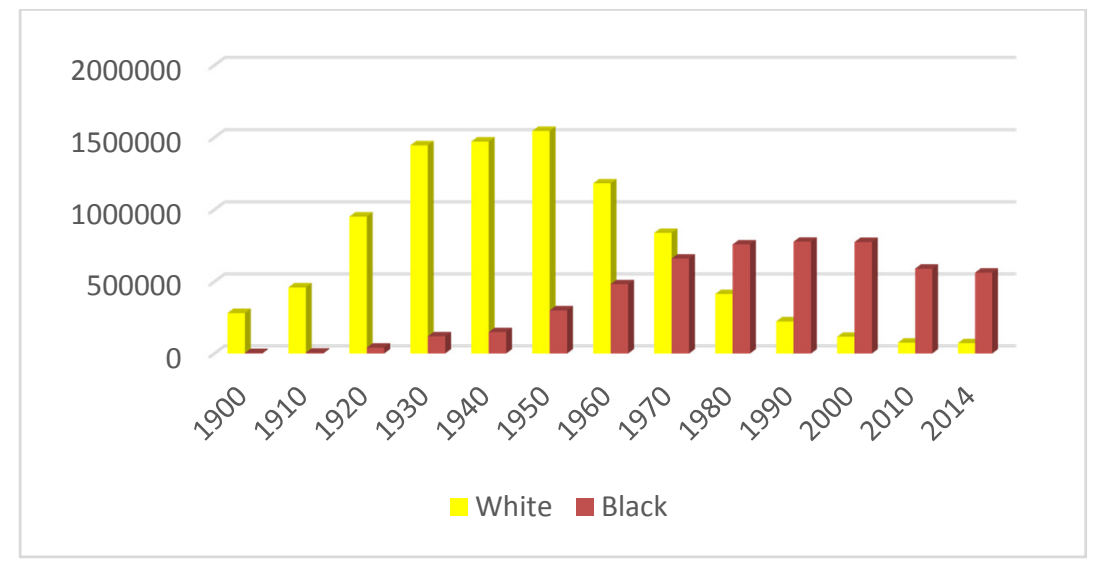

Figure 1: Detroit population by race: 1900-2014.

severe population losses; state policies encouraging suburban development; reductions in revenue sharing to support inner cities; and national priorities that leave cities behind while promoting housing development in the suburbs [12].

Detroit's economic collapse is mirrored in its population exodus; a total loss of 1.1 million people in a period of six decades, including loss of almost a quarter million people between the 2000 and 2010 Census. Figure 2 shows change in population density from 1970 to 2010 . Midtown (highlighted area) has done no better than the rest of Detroit in retaining population. Detroit in 2010 presented a derelict, post-apocalyptic urban landscape showing little evidence of the economic, cultural, and social vibrancy that existed in the City from 1900 to the 1950s.

The number of jobs fell by over half (52.8\%) between 1970 and 2010, and those held by city residents dropped by $43.5 \%$ over the same period. Unemployment has been in double digits during most of this period. Vacancies increased, leaving large areas of Detroit's east and northwest sides derelict or abandoned [15, 16]; roughly 80,000 (23\%) of the 349,170 housing units, $36 \%$ of commercial parcels, $22 \%$ of industrial properties and about 20 square miles of the land area are vacant.

Figure 3 shows change in poverty from 1980 to 2010. The percent of residents in poverty in Detroit has grown considerably over time and is particularly severe post-2000. Despite revitalization of Midtown narratives, poverty increased between 2000 and 2010 there as in the rest of the city. While new entrepreneurs might be opening trendy businesses and restaurants, this has not improved the economic condition of the residents of city generally or even in Midtown.

Detroit's decline is intricately tied to issues of race. The history of intolerance, racism, and extreme segregation was deliberately shaped by public policy [17, 18]. Detroit has consistently been among the top ten US cities with the highest dissimilarity indexes over the past 30 years. The resulting relationship between black Detroit and its mostly white suburbs has been likened to apartheid South Africa [13]. 


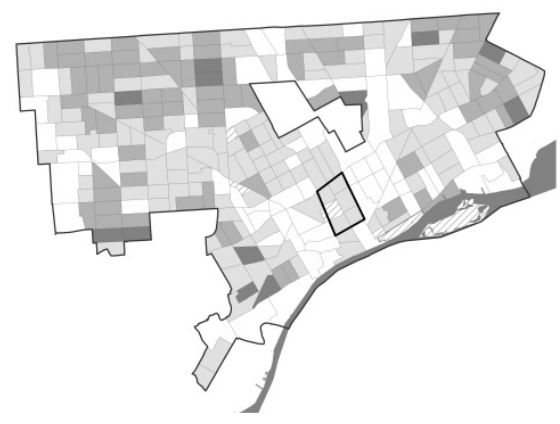

2010

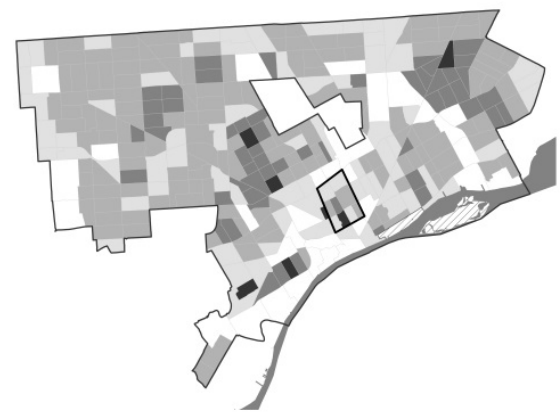

1990

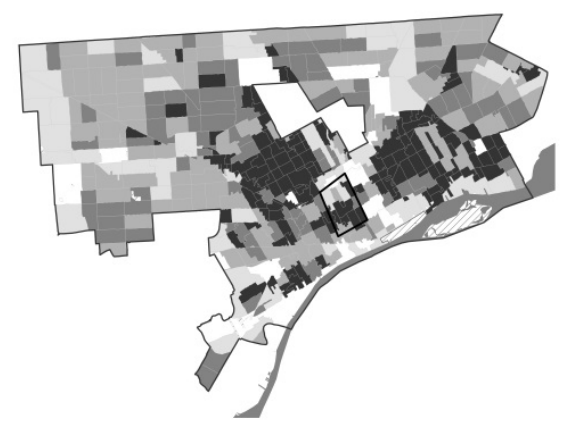

Population per Sq. Km.
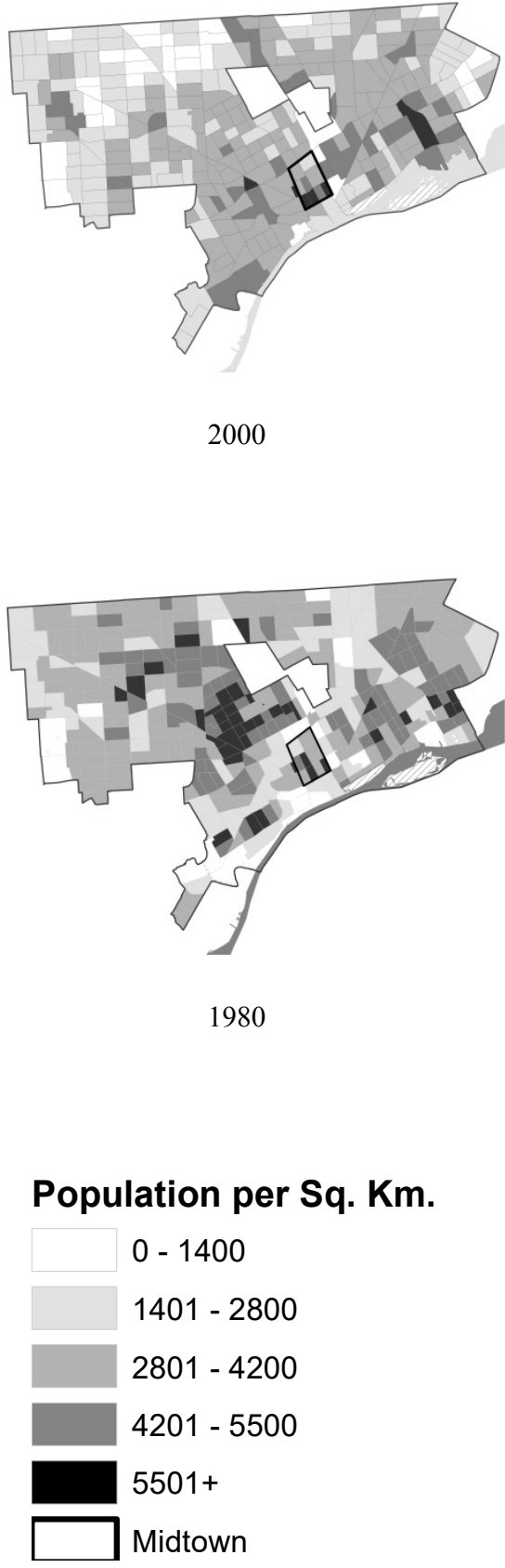

2000

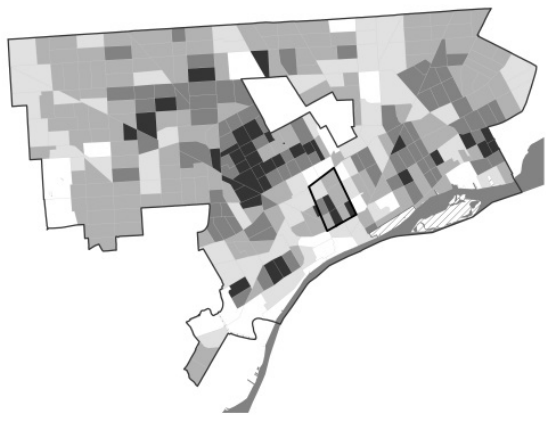

1980

1970

Figure 2: Trends in population density, Detroit: 1970-2010. 


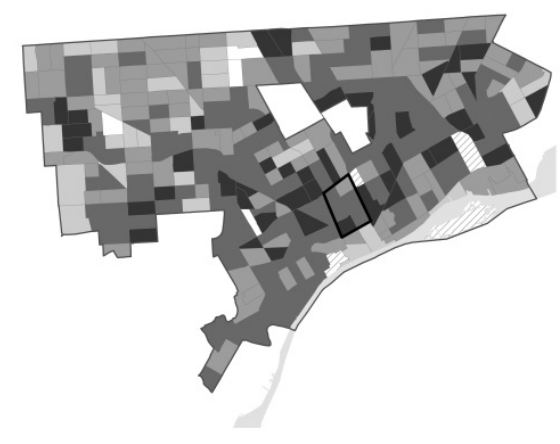

2010

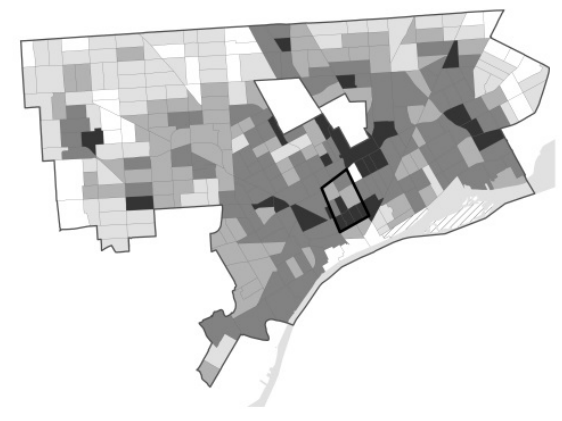

1990

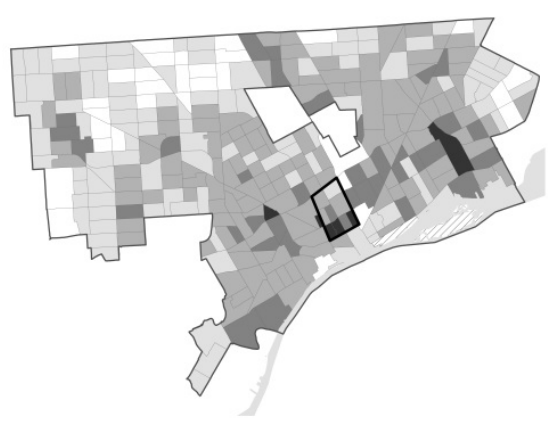

2000

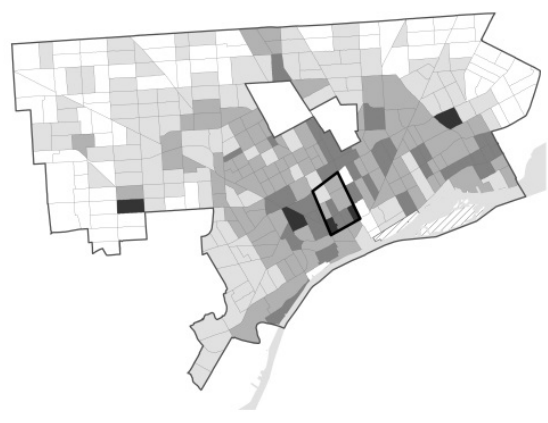

1980

\section{Poverty Percentage}

\begin{tabular}{|c|}
\hline $0.00-10.00$ \\
\hline $10.01-25.00$ \\
\hline $25.01-40.00$ \\
\hline $40.01-55.00$ \\
\hline $55.01-83.00$ \\
\hline Midtown \\
\hline
\end{tabular}

Figure 3: Trends in poverty, Detroit: 1980-2010. 


\subsection{Transition in narratives: from the Cass Corridor to Midtown}

The period following the Great Recession of 2008-09 marked the beginning of a purported improvement in the city. The media narrative in particular has changed since the bankruptcy from generally negative, to mixed, to the quite positive stories appearing in 2015. A variety of sources, ranging from the New York Times, to the Huffington Post, to social media blogs, highlight several themes: the increasing attractiveness of Detroit to young people, particularly entrepreneurs and millennials, because of the low costs of housing, retail and warehouse space, and a market that is wanting for local products and amenities of all types $[5,19,20]$; the burgeoning artistic scene, fueled by low prices for artist housing and workplaces [1]; increasingly vibrant restaurant, nightlife and theatre options [21]; the attractiveness to tourists of these trends plus the continuing opportunity to tour and photograph "ruins" [1]; increasing levels of foreign investment, particularly from China [4, 22]; a gritty, "can-do," and underdog attitude among Detroit residents [22]; the talent pool produced by local universities [24]. While many of these stories do mention the bankruptcy, the burned out buildings, the large swaths of vacant land, the crime, and the poverty, they are increasingly being presented as the back-drop for regeneration - "yes, this is still America's most dangerous city, but it is far from downtrodden" [3]. The dominant Detroit narrative focuses on six square miles of Detroit formerly known as the Cass Corridor, now rebranded as Midtown [25]. The changes most often reported and noted by visitors are occurring in this area.

\subsection{Foundations of change}

What brought about this abrupt change? Detroit's bankruptcy was a key event. The settlement provided the City with a much more manageable balance sheet and opportunities for significant restructuring of public services. An important early development was the decision in 2010 by the Wayne State University Department of Public Safety to expand its patrols to a four square mile area around the University's Main and Medical School campus. Working in cooperation with the Detroit Police Department, WSU has significantly improved the reality and the perception of public safety in Midtown [26].

A number of private sector initiatives also began about this time. Several high tech and financial corporations - including Compuware, Quicken Loans, and Fifth Third Bank - relocated their headquarters to the Central Business District. The private sector funding of cleanup and maintenance activity in Downtown eventually resulted in the creation of a Business Improvement Zone. The nonprofit and foundation community also became active in improvement efforts.

Positive momentum increased, as individuals and small entrepreneurs began to fill in the areas around the major initiatives. College-educated young adults were attracted to Midtown and Downtown. This growing market has attracted new retail, service and entertainment businesses. Such developments also fuel a progrowth boosterism among city officials and business leaders that portrays the city as "an incredible living laboratory where the future of American cities is being demonstrated" [21]. 
The conflicting narratives of Detroit's death and resurrection can largely be accounted for by the fact that they are describing different cities [27]. One is the city as a municipal corporation that has emerged from bankruptcy with its debt washed away but its economic problems (lack of jobs, weak tax base, and increasing costs for antiquated infrastructure) remain. The other is the residents of Detroit. As noted by Eisinger [10], cities cannot really die because their people are still there. And in Detroit, this means a largely African American, primarily poor citizenry. Thus, "repairing the city's balance sheet and demolishing abandoned buildings will not produce a sufficiently level playing field to ensure the prosperity of Detroit's current residents" [27].

\section{Uneven recovery: 2010-}

Is the rhetoric of positive change in Detroit matched by reality? This section examines trends in key indicators over the last five years. While the record is complex, two major conclusions stand out: 1) on a number of measures, Detroit continues to decline, even when positive change has occurred, growth has been much less robust than in other large cities. 2) Within the city, recovery has been highly uneven, resulting in increasing inequality especially between the Downtown and Midtown area and the city's residential neighborhoods.

While other large US cities have seen increases in population since 2000, Detroit's population shrank by 33,500 (4.7\%). Since 2010, citywide statistics for several key economic indicators have been quite mixed. The number of business establishments in the city has declined by about six percent (Table 1). Jobs available at these firms increased by almost four percent and annual payroll grew by $19 \%$. In terms of employment and payroll, however, the record for Downtown is substantially better than the other areas. In both Downtown and Midtown, average wages increased by over $17 \%$, compared to just a $7 \%$ growth rate for neighborhood jobs. Although it represents just 5\% of the city's area, the core included just over half of the job opportunities and more than $62 \%$ of payroll expenditures.

Table 1: Change in Detroit economic indicators: 2010-2013.

\begin{tabular}{|l|c|c|c|c|}
\hline & Establishments & Employees & Payroll & Average wage \\
\hline Detroit & $-6.2 \%$ & $3.7 \%$ & $18.8 \%$ & $13.9 \%$ \\
\hline Downtown & $-11.5 \%$ & $21.7 \%$ & $42.6 \%$ & $17.2 \%$ \\
\hline Midtown & $-7.5 \%$ & $-6.5 \%$ & $9.8 \%$ & $17.5 \%$ \\
\hline Neighborhoods & $-5.2 \%$ & $-0.9 \%$ & $8.1 \%$ & $7.0 \%$ \\
\hline
\end{tabular}

The gap between Detroit's core area (Downtown and Midtown) and its neighborhoods is significant and increasing. Since 2010, the total number of private sector jobs in Detroit increased by about 6,450 , or just under $4 \%$. Downtown businesses added more than 8,450 jobs. During the same period, the number of Detroit residents with jobs fell by 28,400 . 
An important caveat in considering these employment and establishment trends is that data are currently available only through 2013. Media reports suggest that Downtown and particularly Midtown have seen significant numbers of new businesses opening in the past two years. At the same time, business closings in the neighborhoods are local retail and personal service establishments.

American Community Survey data indicate a substantial increase in unemployment rates. The number of unemployed Detroit neighborhood residents rose by 5,600, with modest declines in Downtown and Midtown. The unemployment rate was four percentage points higher in the neighborhoods than in Midtown and 15 points higher than the rate for Downtown residents.

A number of citywide indicators are still trending downward. The population and household gains in Downtown and Midtown have not been sufficient to offset continued declines in the neighborhoods. The overall poverty rate rose by almost five percentage points between 2010 and 2014, according to the ACS. Median household income, in current dollars fell by just over $\$ 2,000$, a decline of $7.2 \%$. Even Downtown and Midtown remain works in progress. Just two blocks away from Detroit's Campus Martius Park, the city's two newest office buildings and new light rail line, a community garden has replaced a ten-story office building.

Vacancy rates in Detroit's neighborhoods and Midtown rose to almost 30 percent, from 79,000 to 106,500 . The vacancy rate in Downtown fell by more than six percentage points but remained at $20 \%$. Again, these data are the most current but are close to two years old. The City has reportedly demolished 9,000 residential structures in the last two years, equivalent to a decline of three percentage points in the citywide vacancy rate. Anecdotal information puts the current vacancy rate in Midtown at less than $5 \%$.

The price of housing in Detroit (Figure 4) reflects these trends. Home prices in Downtown and Midtown are clearly much higher than in Detroit's neighborhoods and they are increasing much more rapidly. In 2010, the average sales price of a home (most likely a condominium) in Downtown Detroit was six and a half times the average sales price in the neighborhoods; in 2014, the ratio had increased to 7.6. In 2014 the average sales price in Midtown had risen to 5.8 times the neighborhood figure, from 4.2 times in 2010. One contributing factor in the low neighborhood sales prices is the high proportion of foreclosure sales, which are often heavily discounted. In 2014 , over $41 \%$ of these transactions were short sales or REO sales; the comparable figures for Downtown and Midtown were zero and $15 \%$, respectively.

There are, of course, considerable differences among Detroit neighborhoods. In 17 of the ZIP Code-defined neighborhoods, the average sales price increased by less than $\$ 10,000$ between 2010 and 2014, while Downtown and Midtown sales prices rose by $\$ 67,000$ and $\$ 60,800$, respectively. (In the neighborhood south of Detroit City Airport average sales prices declined by about one-third during this period.) In the neighborhood just west of Midtown, which includes the Woodbridge community, average sales prices increased by $\$ 72,500$. Several other neighborhoods close to the core area recorded price increases in the $\$ 19,000$ to $\$ 28,000$ range. 


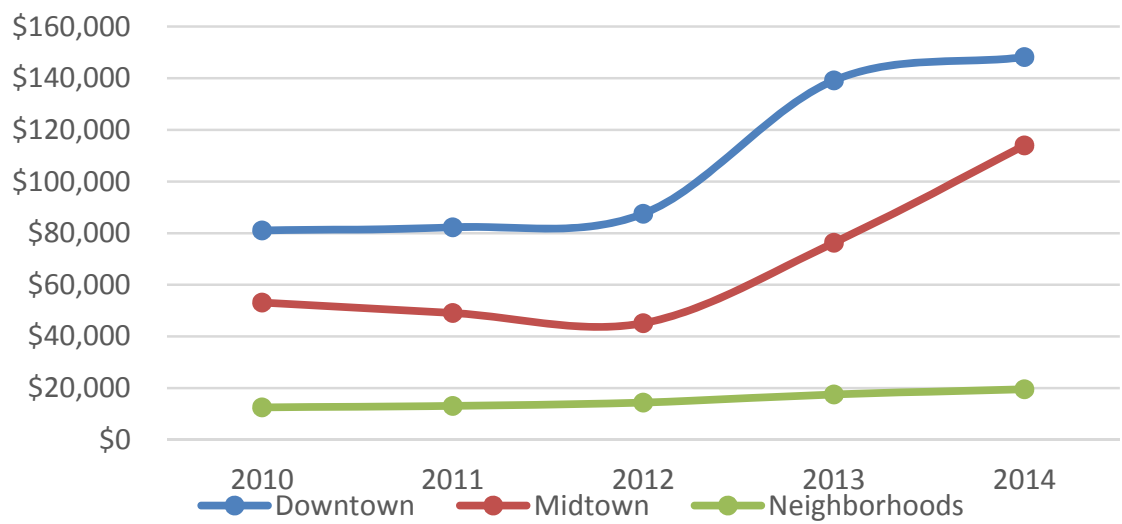

Figure 4: Average residential sales prices Detroit: 2010-13.

Adaptation to these new realities requires significant changes to the built environment and land use. The City has demolished some 9,000 housing units since 2014. To address the steadily increasing glut of vacant land, Detroit has introduced new categories of use. The Detroit Future City report [28] calls for 50 square miles (out of a total of 140) to be devoted to parks and landscape areas, including lakes and carbon forests. About 20 square miles would be redeveloped as low-density "green" neighborhoods. Within a few miles of the central business district, the City has turned 60 acres over to a non-profit organization for truck gardening. An additional 160 acres are being developed as a tree farm. The substantial task of addressing the needs of neighborhood residents, however, has barely begun. Residential and neighborhood commercial areas are being converted to open space and ecological reserves, industrial parks, commercial agriculture and transportation facilities. Physical capital in the neighborhoods - utilities and public buildings - is being upgraded, but only selectively.

While these physical development strategies are beginning to bear fruit, much too little is being done to strengthen human capital. Recent improvements in citywide statistics are largely the result of importing jobs and well-educated employees into the core.

\section{Discussion and policy implications}

"If we can rebuild Detroit, we can rebuild anything" [26].

Since the Great Recession (2008-10), there are some signs that Detroit's prospects have begun to improve. The bankruptcy settlement has greatly improved the City's balance sheet. More people, including young adults Millennials and artists, are moving into Detroit; the city's long population decline has slowed. There have been improvements in some public services, such as the municipal water and sewer system and public lighting. The decline in housing prices has leveled off 
with a significant rebound occurring in select areas of Detroit. Plans for Detroit's future accept that the city will not return to its former population and economy any time soon, if ever.

Yet, the modest recovery in Midtown presents some lessons that could be applied to redevelopment in other areas of the city; the following appear to be contributing forces:

- A significant increase in police presence and a concomitant increase in perceptions of public safety.

- Relative concentration of retail and food establishments allowing for a density of options and visitors on the streets.

- Major anchoring institutions in the form of Wayne State University and the Detroit Medical Center.

- Cooperative efforts of corporations and foundations.

- Good public relations via both traditional and social media.

Despite these improvements, serious problems remain and it will be difficult to achieve the same results in the rest of the city. Critical public services still require vast improvements. Although there is currently a great deal of discussion about the need for improvements to public education in the city, these have focused on financial issues and the physical condition of school buildings. For residents in many Detroit neighborhoods, access to high quality education, job skills and employment opportunities remains limited. Close to 300,000 Detroiters are living in poverty and 85,000 are unemployed. Too few Detroit residents have the education, training, and skills necessary to successfully compete in the labor market, even if the number of available jobs increases.

What does the future hold for Detroit? Will the pace of recovery in Downtown and Midtown be rapid enough to offset the continued decline of the city's neighborhoods? Will there be sufficient growth in Detroit's tax base to support improvements in critical public services and the quality of life for all residents? Will Detroit be able to retain and attract enough middle and upper income residents to reduce the high concentration of poverty? Will racism continue to drive a wedge between the poor, black central city and its more affluent, mostly white suburbs? Future research, allowing for a greater passage of time should examine these questions potentially employing urban and economic simulation modeling to allow for comparisons to the evolution and development of other shrinking cities. At this time, it is difficult to imagine that there will be positive answers to all of these questions. And, if only some of the essential changes occur, it seems unlikely that the current Great Expectations for Detroit will be realized.

\section{References}

[1] Kugel, S. In Detroit, cheap eats, D.I.Y. art and the charm of locals. New York Times, 2015.

[2] Swanson, B. Is Detroit making a comeback? http://www.Housingwire .com/articles/print/35012-is-detroit-making-a 
[3] Coad, J. Is Detroit America's comeback kid? Virgin Atlantic thinks so and has started flying direct from London. www.dailymail.co.uk/travel/article3140713/Is-Detroit-America-s-comeback-kid-Virgin-Atlantic-thinksstarted-flying-direct-London.html

[4] Cwiek, S. No, Chinese investors aren't 'buying up Detroit' - but they do have an eye on the Motor City. http://michigan radio.org/post/no-chineseinvestors-arent-buying-detroit-they-do-have-eye-motor-city\#stream/0

[5] Conlin, J. Detroit pushes back with young muscles. www.Ny times.com/2011/07/03/fashion/the-young-and-entrepreneurial-move-todowntown-detroit-pushing-its-economic-recovery.html

[6] Pallagst, Karina. Shrinking Cities. Routledge, 2015.

[7] Rieniets, Tim. "Shrinking cities: causes and effects of urban population losses in the twentieth century." Nature and Culture 4(3): 231-34. 2009.

[8] Wiechmann, Thorsten, and Marco Bontje. Responding to tough times: Policy and planning strategies in shrinking cities. European Planning Studies 23, no. 1 (2015): 1-11.

[9] Hollander, J., M. P. Johnson Jr, and E. D. Whiteman. "Supporting Shrinkage: Better Planning and Decision-Making for Shrinking Cities." 2016.

[10] Eisinger, P. Is Detroit dead? Journal of Urban Affairs 36(1), pp. 1-12, 2013.

[11] Ryan, B.D. Design after decline: How America rebuilds shrinking cities. University of Pennsylvania Press: Philadelphia, 2012.

[12] Galster, G. Driving Detroit: The quest for respect in the motor city. University of Pennsylvania Press: Philadelphia, 2012.

[13] Reese, L.A. Sands, G. and Skidmore, M. "Memo from Motown: is austerity here to stay?" Cambridge Journal of Regions, Economy and Society. 7(1): 101-118, 2014.

[14] LeDuff, C. Detroit: An American autopsy. Penguin Books: New York, 2013.

[15] Macdonald, C. and Wilkinson, M. Half of Detroit property-owners don't pay taxes. Detroit News.

[16] Urban, N. and Sands, G. City of Change. Data Driven Detroit, 2014.

[17] Farley, Reynolds. "The Bankruptcy of Detroit: What Role did Race Play?" City \& Community 14, no. 2 (2015): 118-137.

[18] Vojnovic, I. and Darden, J. Class/racial conflict, intolerance, and distortions in urban form: Lessons for sustainability from the Detroit region. Ecological Economics 96, pp. 88-98, 2013.

[19] Tomlimson, M. A millennial paradise: How once-bankrupt Detroit is making a comeback. www.elitedaily,com/life/detroit-next-american-uccess/114 $\underline{5067 /}$

[20] Ager, S. Tough, cheap, and real, Detroit is cool again. National Geographic, www.nationalgeographic.com/taking-back-Detroit/see-detroit.html

[21] Tabb, W.K. If Detroit is dead, some things need to be said at the funeral. Journal of Urban Affairs 37 (1), pp. 1-12, 2015.

[22] Brecher, J. 2014 (November, 22). Chinese investors snap up property in bankrupt Detroit. http://www.nbcnews.com/ news china/chinese-investorssnap-property-bankrupt-detroit-n253186 
[23] Barnes, S.B. Detroit: Rebuilding and ready for a comeback. USA Today, www.experience.usatoday.com/america/story/road-trips/2015/07/27/ detroit-rebuilding-ready-comeback /30741857/

[24] Bruni, F. (September, 9). The spirit and promise of Detroit. New York Times, 2015.

[25] Cowley, S. (February, 25). How Wayne State police helped breathe life into a blighted Detroit strip. New York Times, 2015.

[26] Hauser, C. Amazon envisions a new tech hub as it expands its Detroit presence. New York Times, 2015.

[27] Sands, G. Not dead yet: Response to William Tabb's 'If Detroit is dead, some things need to be said at the funeral.' Journal of Urban Affairs 37(1) pp. 13-16, 2015.

[28] Detroit Future City. Strategic Framework. Detroit Future City: Detroit, 2013. 